DOI: $10.24143 / 2073-5529-2019-3-17-30$

UDK 639.2/7.3 (282.255.2)

\title{
MODERN STATUS AND PROSPECTS OF ARTIFICIAL BREEDING OF RARE, EXTINCTING FISH SPECIES FOR CONSERVATION OF BIODIVERSITY AND RESTORATION OF ABUNDANCE IN NATURAL WATER RESERVES OF THE ILE-BALKHASH BASIN
}

\author{
K. B. Isbekov ${ }^{1}$, S. Zh. Assylbekova ${ }^{1}$, D. K. Zharkenov ${ }^{1}$, V. N. Tsoi ${ }^{1}$, M. A. Zhaparova ${ }^{2}$ \\ ${ }^{1}$ Fisheries Research and Production Center, LLP \\ Republic of Kazakhstan, Almaty \\ ${ }^{2}$ Kazakh National Agrarian University, \\ Republic of Kazakhstan, Almaty
}

\begin{abstract}
This article presents materials on the current state of the native ichthyofauna of the Ile-Balkhash basin, affected by large-scale acclimatization works. Four species of the ichthyofauna composition are listed in the Red Book of Kazakhstan: spike (Acipenser nudiventris Lovetsky, 1828), Aral barbel (Barbus brachycephalus brachycephalus Kessler, 1872), Balkhash marinka (Schizothorax argentatus argentatus Kessler, 1874), Balkhash perch (Perca schrenkii Kessler, 1874). Due to the ineffectiveness of fish conservation measures, including the prohibition for catching of these fish species, which are not found anywhere except in the Ile-Balkhash basin, it is necessary to impose artificial reproduction, changes in the Fishery Rules and organization of commercial rearing. The work is based on research materials of 2001-2018 conducted in Lake Balkhash, the delta and the lower reaches of the Ile and the Tokraun. The status of spike populations (Acipenser nudiventris Lovetsky, 1828), Aral barbel (Barbus brachycephalus brachycephalus Kessler, 1872), Balkhash marinka (Schizothorax argentatus argentatus Kessler, 1874) and Balkhash perch (Perca schrenkii Kessler, 1874). The main reasons preventing the maintenance of a high number of endangered species have been established: small area of natural spawning grounds, death of fry in linmeshing fishing gear, large-scale poaching (spike); deterioration of conditions for the natural reproduction, mass mortality of young fishes in the irrigation system (Aral barbel); total elimination and food competition with pike perch (Balkhash marinka, Balkhash perch). The prospects for preservation of rare and endangered fish species have been considered, recommendations for breeding and replenishing populations of species listed in the Red Book have been given: measures for artificial reproduction and prevention of juvenile death, creating favorable conditions for fattening and reducing the pressure of trophic competition. Without taking adequate measures for reducing the anthropogenic impact on natural resources, including ichthyofauna, the number of main commercial fish species will decrease, rare species of fish will die out.
\end{abstract}

Key words: the Red Book, migration, Aral barbel, Balkhash perch, ship, Balkhash marinka, basin.

For citation: Isbekov K. B., Assylbekova S. Zh., Zharkenov D. K., Tsoi V. N., Zhaparova M. A. Modern status and prospects of artificial breeding of rare, extincting fish species for conservation of biodiversity and restoration of abundance in natural water reserves of the Ile-Balkhash basin. Vestnik of Astrakhan State Technical University. Series: Fishing Industry. 2019;3:17-30. (In Russ.) DOI: 10.24143/2073-5529-2019-3-17-30.

\section{Introduction}

Today conservation of biodiversity is a pressing issue. This idea is reflected in the international Convention "On Biological Diversity" [1], which has been ratified by the Republic of Kazakhstan. By decision of the UN, the period 2011-2020 was declared the decade of biodiversity.

$30 \%$ of 24000 fish species in the world are listed as endangered [2]. At the turn of the millennium ecosystem assessment has shown that in the last few decades, about $20 \%$ of freshwater fish species have been listed as endangered or vanishing.

The lost selection species of fish and animals are possible to restore, but the extinct natural populations and species cannot be returned, since their unique gene pool is lost.

In Kazakhstan 18 species, subspecies and populations of fish and fish-like species out of 157 fish species / subspecies are listed in the Red Book. The main factor affecting the ichthyofauna of Kazakhstan's water bodies was introducing of commercial fish species in order to "improve" the quality of fish products, as well as large-scale construction of hydroelectric stations and nonrational fishing. 
As a result of works on acclimatization, the ichthyofauna of Kazakhstan was replenished with dozens of species of planned and random invaders.

Ichthyocenoses of the Ile-Balkash basin were most affected by large-scale acclimatization measures. Initially, the aboriginal ichthyofauna of the basin consisted of 10 species, of which 5 lived in Lake Balkash. Two of them - Balkhash marinka and Balkhash perch- are endemic to the Balkhash ichthyological province [3]. During the period from 1905 to 2005, 22 species were naturalized in the process of acclimatization in the Ile-Balkash basin, of which were planned only 11 species.

At present, four species of the ichthyofauna of the basin are listed in the Red Book of Kazakhstan:

1. Barbel sturgeon - Acipenser nudiventris Lovetsky, 1828;

2. Aral barbel - Barbus brachycephalus brachycephalus Kessler, 1872;

3. Balkhash marinka - Schizothorax argentatus argentatus Kessler, 1874;

4. Balkhash perch - Perca schrenkii Kessler, 1874.

As it turned out, introducing a ban on fishing these species (listed into the Red Book of Kazakhstan) did not lead to stabilization of their numbers. The currently undertaken conservation measures are ineffective; they do not eliminate the reasons for the decline in abundance.

It is quite obvious that challenging measures should be used to save from extinction the rare species of the Ile-Balkhash basin. Dying away of marinka and perch from catches, and later from ichthyocenosis of the Ile-Balkash basin can bring these two species to extinction. The Aral spike has already died out in the Aral-Syr Darya basin and the Ile-Balkash population of this species has become unique in the world. Aral barbel occurs in insignificant amounts in the middle course of the Syr Darya river.

In the event of extinction of the Ile-Balkash population, the Syr Darya barbel will remain the last. Thus, the restoration and maintenance of stable abundance of rare fish species in the Ile-Balkash basin is important for conservation of the global biodiversity, as these fish are not found anywhere else.

\section{Materials and research methods}

The research is based on the annual surveys of Lake Balkhash and the Ile delta in 2001-2018, the lower reaches of the Ile close to Araltobe village in 2004-2018, as well as survey data on the Tokyraun river in 2001-2003 and 2013-2018 [4].

Sampling was carried out according to a standard grid of stations including 60 stations on Lake Balkhash, 9 stations in the Ile delta and stationary sampling post on the Ile near Araltobe village. In total, in Lake Balkhash the nets were set 722 times, in the Ile delta and channel - 253, in the Tokyraun river -36 . There were made 528 raftings along the Ile river.

In addition to their own catches, there were analyzed net and seine catches of fishermen. 52535 fishes were processed, including the protected species.

Collecting and processing data was carried out according to generally accepted methods. When the representatives listed in the Red Book of the Republic of Kazakhstan were caught, their body length was measured and they were set free into the water $[5,6]$. In the course of the research there were used the open published materials, as well as databases of KazNIIRKh, Scientific and Industrial Centre of Kazakhstan and Kazakh State University.

\section{Research results and discussion}

Characterization of the status of populations of Acipenser nudiventris Lovetsky, 1828 - Ship. In its natural state, ship can be found in the basins of the Black, Azov, Caspian and Aral Seas. In the Aral Sea basin ship is extinct. It is currently found in Kazakhstan in the Ural-Caspian and Ile-Balkhash basins.

In the Aral Sea, ship stocks were abundant. The Syr Darya river was its main spawning ground. In the Amu Darya river it was found in smaller quantities. In the Aral Sea there occurred two races of this species: winter race and scares spring race.

Into the Ile-Balkhash basin ship was brought from the estuary of the Syr Darya river in 1933-1934. By 1970 adult ship species and their juveniles had been found in all areas of the lake and throughout the Ile River up to the Chinese border. Ship didn't enter the Ayagoz, Lepsy and Aksu rivers. In the Karatal river the adult ship species were periodically caught by poachers, but there is no data on catching ship juveniles [7].

After building the Kapshagai hydroelectric station, the whole Ile-Balkhash ship stock was divided into Kapshagai stock and Balkhash stock. By the mid-1980s the number of fish significantly decreased due to a sharp reduction of spawning areas and worsening conditions for the development of sturgeon juveniles. 
Currently, ship in Lake Balkhash is scarce. In the west of Balkhash it never occurs, due to the increasing number of aged mollusk groups of Monodacna colorata (Eich.), which serve as food for ship and large carp species, as well as due to reducing the number of poaching gear used specifically for catching sturgeon. In the east of Balkash, ship is still found sporadically in the coastal waters of the islands of Ultarakhta and Korzhun. The fish goes up to spawn to the Ushtobinsky hydroelectric dam. In this part of the lake immature ship individuals occur in seine catches. In 2016 in the waters of Korzhun Island there was registered a ship species with a body length of $62 \mathrm{~cm}$ and mass $1.7 \mathrm{~kg}$, which corresponded to a six year old species.

In the Ile delta ship's habitats are concentrated around the lakes Ir-Maitan, Ainakol, Shagyray, and others. But year after year the facts of catching sturgeon juveniles become less common, which speaks of the minor natural reproduction of the species in the Ile-Balkhash basin.

After the Ile river flow regulation the main places for ship reproduction were the sections of the Ile 70-80 km lower the Kapshagay dam with characteristic hard ground (gravel, coarse sand).

As shows the analysis of ship habitat conditions in the Aral - Syr Darya and Ile-Balkhash basins, the Aral ship has found suitable conditions and successfully naturalized in the Ile-Balkhash basin. The following reasons hindered the size of the stock: small area of natural spawning grounds; death of fry in obsessive gear; intensive illegal fishing; trophic competition with other benthophages in Lake Balkhash.

Characteristics of the population of Barbus brachycephalus brachycephalus Kessler - Aral barbel. Aral barbel being a subspecies of short-headed barbel was found in its natural state in the basins of the Caspian and Aral seas. Currently, the self-replicating brood stock of Aral barbel can be found on the territory of Kazakhstan only in the Syr Darya river.

During fattening in the Aral Sea, Aral barbel mainly ate benthos (mollusks, gammarus, chironomide larvae, etc.).

After successful acclimatization of Nereis polychaete in the Aral Sea Aral barbel moved on to polychaete worms.

At present, abundance of Aral barbel in the Chardara Reservoir and in the lower course of the Syr Darya river is insignificant. In 2003 in the Arys river at a distance of $35 \mathrm{~km}$ from the Shaulder hydroelectric station there were conducted studies on pelagic roe and barbel larvae roll down; the research results helped to calculate the number of producers at spawning grounds. It was found that only about 200 producers of this species live in the area.

In 2018 in the Syr Darya below the Aytek dam (the Kyzylorda region) 16 species of Aral barbel were caught by a gill net. Analyzing the size, weight and age of the caught fish (Table 1), it should be noted that these individuals belong to the non-migratory form, which reside and reproduce in the Syr Darya. Their growth rate is low due to the weak development of benthic organisms in the river.

Table 1

Biological indicators and age composition of Aral barbel in the Syr Darya in August 2018

\begin{tabular}{|c|c|c|c|c|c|c|c|}
\hline \multirow{2}{*}{$\begin{array}{c}\text { Age, } \\
\text { years old }\end{array}$} & \multicolumn{2}{|c|}{ Length, cm } & \multicolumn{2}{|c|}{ Mass, $\mathbf{g}$} & \multirow{2}{*}{ Fulton Fatness } & \multirow{2}{*}{$\begin{array}{c}\mathbf{N}, \\
\text { individuals }\end{array}$} & \multirow{2}{*}{$\begin{array}{c}\text { Share of } \\
\text { fish in catch, } \\
\%\end{array}$} \\
\hline & $\min -m a x$ & average & $\min -\max$ & average & & & \\
\hline $4+$ & $22-35$ & 28.7 & $461-705$ & 585 & 2.47 & 11 & 68.8 \\
\hline $5+$ & $36-40$ & 38.0 & $730-901$ & 793 & 1.44 & 3 & 18.8 \\
\hline $6+$ & 45 & 45.0 & 983 & 93 & 0.87 & 1 & 6.2 \\
\hline $8+$ & 63 & 63.0 & 1380 & 1380 & 0.55 & 1 & 6.2 \\
\hline Total & $22-63$ & 38.1 & $461-1380$ & 698 & 2.05 & 16 & 100,0 \\
\hline
\end{tabular}

In 1930-1931 Aral barbel from the lower reaches of the Syr Darya was invaded into the Lake Balkhash. In the first years after moving in of Aral barbel it could occasionally be found in catches, but then it vanished until 1949, which was considered as a failure of acclimatization. Later, uneven-aged Aral barbel again occurred in different parts of the basin. At present, it is rather scarce in the western part of Lake Balkhash, it can be occasionally caught in the Ile river, all the way from the estuary to the dam of the Kapshagay hydroelectric station. 
In Lake Balkhash Aral barbel eats mainly monodacna. However, the main part of the growing season the fish spends in the Ile river, where it eats peculiar food - weed and detritus and, to a much lesser extent, protein food - mysids, gammarus and chironomid larvae.

The population of Aral barbel in the Ile-Balkhash basin is small. In 1982 in the lower reaches of the Ile river the number of its spawning school reached $3000-3.500$ species.

In the Kapshagai reservoir the abundance of Aral barbel is even less.

In 2005, according to the size of roe roll down in the Ile river, the breeding number of Aral barbel became 30 times less. Studies of the roll down of pelagic roe and prelarvae carried out in 2012-2018 showed that there was practically no natural reproduction of Aral barbel in the lower reaches of the Ile river. The last fact of catching adult Aral barbel in Lake Balkhash dates back to 2015.

The main factors that adversely affected the abundance of Aral barbel in the reservoirs of the Aral-Syr Darya and Ile-Balkash basins were the following: deterioration of the conditions of natural reproduction; large by-catch of young fish by fixed nets; mass mortality of Aral barbel juveniles in the irrigation system; poaching.

Characteristics of populations of Schizothorax argentatus, argentatus Kessler - Balkhash marinka. In the initial state, Balkhash marinka was widely distributed throughout the waters of the Ile-Balkhash basin, inhabiting all types of reservoirs, from mountain streams to large terminal reservoirs (Fig. 1).

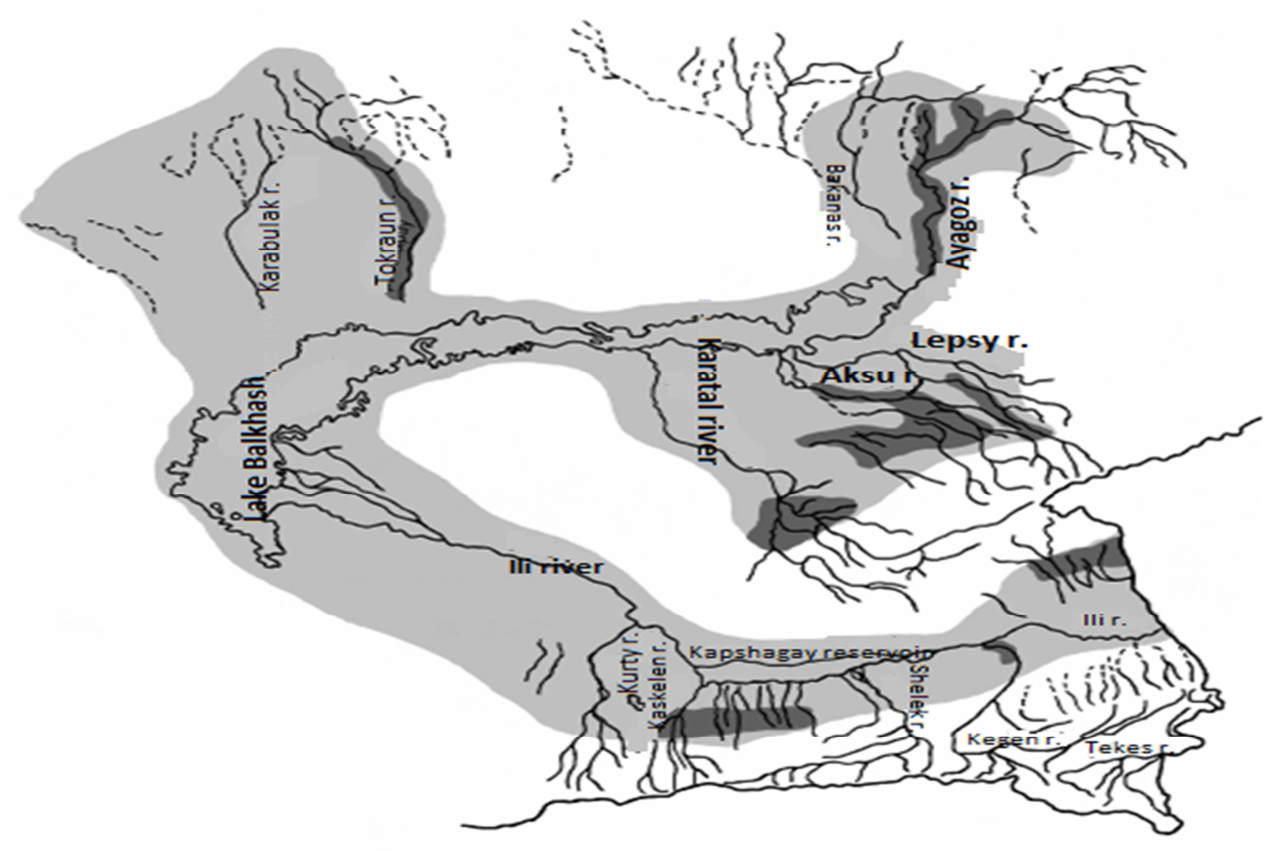

The initial distribution

Modern distribution

Fig. 1. The area of the Balkhash marinka in the reservoirs of the Ile-Balkhash basin

The situation arose in the result of elimination of smaller marinka males by pike perch.

Analysis of the age composition of commercial catches shows that marinka stocks were in poor condition. The percentage composition of marinka replenishment (new spawning fish $-4+-5+$ ) and the rest marinka (6+ and older) shows that within 1961-1966 there was a slow replenishment of the stock; in 1966-1971 it stopped, the remnants of marinka generations of 1961-1965 were caught. As a result, marinka stocks were severely damaged and the weak replenishment that had begun since 1972 could not contribute to the rapid recovery of marinka size (Fig. 2). 


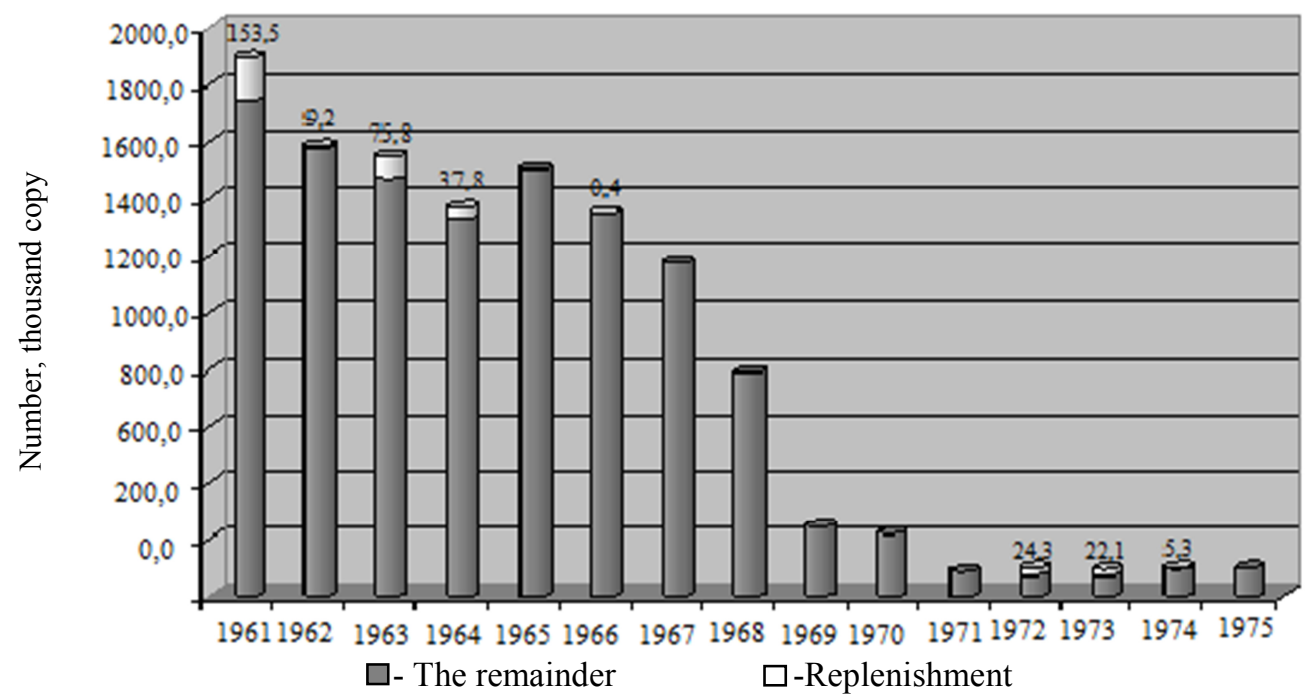

Fig. 2. Dynamics of the age structure of marinka in Lake Balkhash

All these changes led to reducing marinka reproduction. The occurrence of marinka juveniles in the control catches dropped from 60\% in 1961 to $11 \%$ in 1968 and to 5\% in 1969. In 1970 marinka juveniles in Lake Balkhash didn’t occure. Marinka reproduction severely lowered [8].

Today marinka distribution is limited by a few sectors of the basin. Distribution analysis shows that marinka has survived on those streams which, for whatever reasons, were isolated from acclimatizers. The Tokiraun river that brings its waters to the north part of Lake Balkhash is of greatest interest of all the rivers.

Studies conducted in 2013-2018 showed that a rather numerous marinka stock inhabits the upper and middle part of the river. According to the results of a brief morphological analysis, it can be inferred that marinka from the Tokyraun river due to its comparative meristic and phenotypic traits can be attributed to Balkhash marinka as a species. Its biological characteristics are shown in Table 2.

Table 2

Biological characteristics and age composition of Balkhash marinka in the Tokiran river in 2018

\begin{tabular}{|c|c|c|c|c|c|c|c|}
\hline \multirow{2}{*}{$\begin{array}{c}\text { Age, } \\
\text { years old }\end{array}$} & \multicolumn{2}{|c|}{ Length, cm } & \multicolumn{2}{|c|}{ Mass, $\mathbf{g}$} & \multirow{2}{*}{$\begin{array}{l}\text { Fulton } \\
\text { Fatness }\end{array}$} & \multirow{2}{*}{$\begin{array}{c}\mathbf{N}, \\
\text { individuals }\end{array}$} & \multirow{2}{*}{$\begin{array}{c}\text { Share } \\
\text { of fish in catch, \% }\end{array}$} \\
\hline & $\min -\max$ & average & $\min -\max$ & average & & & \\
\hline $2+$ & 14 & 14.0 & $40-42$ & 41 & 1.49 & 2 & 2.4 \\
\hline $4+$ & $21-23$ & 22.2 & $128-188$ & 155 & 1.41 & 5 & 6.1 \\
\hline $5+$ & $24-26$ & 25.3 & $186-252$ & 224 & 1.38 & 19 & 23.2 \\
\hline $6+$ & $26-28$ & 27.1 & $252-362$ & 292 & 1.49 & 23 & 28.0 \\
\hline $7+$ & $29-32$ & 30.2 & $330-554$ & 418 & 1.52 & 18 & 21.9 \\
\hline $8+$ & $32-36$ & 33.8 & $458-690$ & 565 & 1.48 & 9 & 11.0 \\
\hline $9+$ & $36-37$ & 36.7 & $728-809$ & 757 & 1.53 & 3 & 3.7 \\
\hline $11+$ & $42-45$ & 43.3 & $1128-1332$ & 1209 & 1.50 & 3 & 3.7 \\
\hline Total & $14-45$ & 28.4 & $40-1332$ & 371 & 1.47 & 82 & 100.0 \\
\hline
\end{tabular}

Analyzing the table data, it can be said that the growth rate of marinka from Tokyraun is not high, in the stock there dominate species at the age of 5+-7+ years (their total share in the catch is $73.1 \%$ ). The catches of marinka juveniles in the reaches of the Tokyraun by dragging nets gave 10 specimens per one catch, which shows a good natural reproduction in the habitat.

The estimated number of commercial stocks of Balkhash marinka makes 4.500 species.

After extinction of marinka in Lake Balkhash the question of possible restoring its numbers in the mother's reservoir was repeatedly raised. The technology of marinka artificial reproduction was developed using producers of natural origin. It was implied that living conditions for marinka were optimal, since this was its native water reservoir. The technology was successfully tested on the Ile and 
Lepsy. It was planned to build two hatcheries for artificial reproduction of marinka in the Ile delta near Kuygan village and in the lower reaches of the Karatal river. However, these plans were not realized.

It should be mentioned that the problem of restoration of marinka abundance in Lake Balkhash and its tributaries has remained controversial. Marinka endangered due to destruction of its habitat, namely, changes in its biotic part. In this regard, some researchers believe that in order to successfully restore marinka populations in natural reservoirs it is necessary to fundamentally change the composition of commercial ichthyofauna there.

Bearing in mind that today the ichthyocenoses of most lowland reservoirs of the BalkhashAlakol basin consist of acclimatizers, it is necessary to catch most number of acclimatizers and only after that to start the reproduction and reintroduction of marinka, which looks unreal.

According to other specialists, marinka successfully grew and multiplied both with the aboriginal composition of the ichthyofauna of Lake Balkhash and after acclimatization in the basin of other fish species such as carp, thorn, bream, crucian carp, grass carp. elimination of its perch. It was after the successful acclimatization of the pike perch in the Ile-Balkhash basin and the achievement of its commercial population, the number of the marinka population and catches began to fall steadily (Fig. 3).

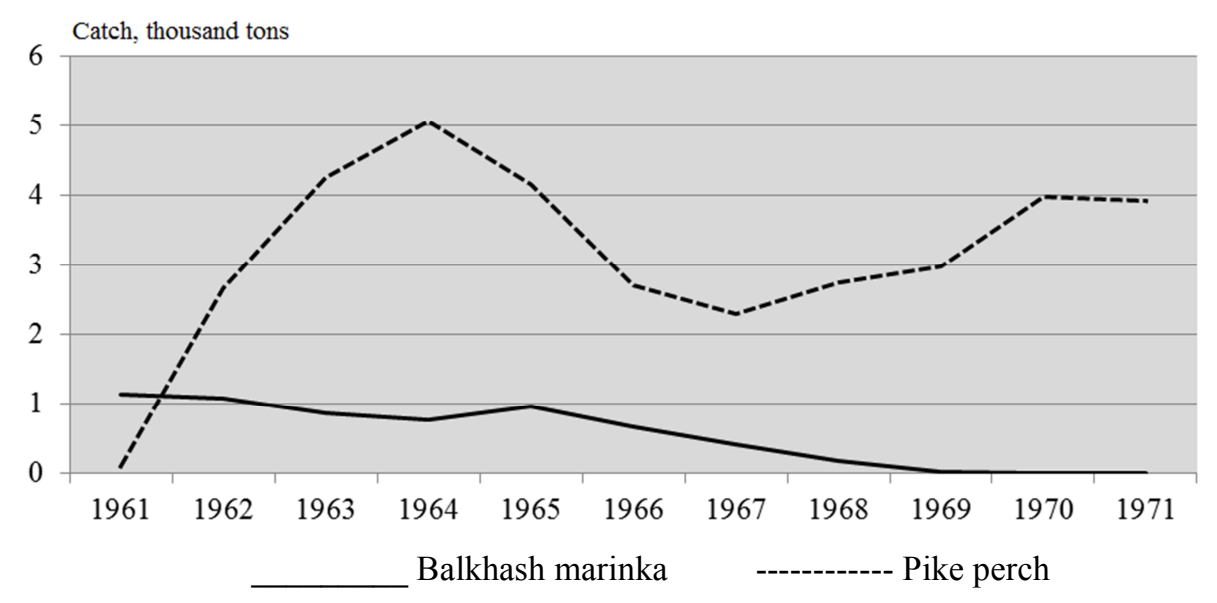

Fig. 3. Dynamics of catches of Balkhash marinka and pike perch in Lake Balkhash

Analysis of the graph in Fig. 3 shows that since 1961 when pike perch became the commercial fish, marinka catches from 1.140 tons dropped to zero by 1971. The same thing happened to Balkhash perch. Actually, in 10 years pike perch has almost completely eliminated two endemics of Lake Balkhash.

The number of pike perch during these years was so high that its catches reached 5.050 tons. For comparison, in 1997 the total annual production of all commercial fish species on Lake Balkhash amounted to 5.060 tons. In 1965, after invading and successful acclimatization of Caspian roach, it became the main food in the nutrient budget of pike perch. The ongoing intensive fishing of pike perch in the 1970s-90s led to a significant reduction of its numbers in the Ile-Balkhash basin.

The increased commercial demand in the European market since the beginning of the XXI century has further increased the fishing pressure on pike perch. In recent years the commercial stocks of pike perch on Lake Balkhash has stabilized at the level of 2.500 tons, which allows limiting its catches to 750 tons. Thus, in the case of reintroduction of marinka into Lake Balkhash it is quite logical to assume that its relations with pike perch in the interspecific relationship 'predator-prey' won't be so tense.

Balkhash marinka may occupy a certain niche in the biocenoses of Lake Balkash and rivers flowing into it [9].

Characteristics of populations Percaschrenkii Kessler, 1874 - Balkhash perch. Balkhash perch, like Balkhash marinka, is endemic to the Balkhash ichthyological province. In the initial state in Lake Balkhash and in the planes near its tributaries (the Ile, Karatal, Aksu, Lepsi, Ayagoz, Tokraun rivers) it was found everywhere [10]. 
Balkhash perch was found along the whole Ile river, from the delta to the state border and upper, it went up to all the channels, standing the flow rate more than $1 \mathrm{~m} / \mathrm{s}$. Balkhash perch went up the tributaries to an altitude of 700-800 $\mathrm{m}$ above sea level, occurring mainly in ponds (Fig. 4).

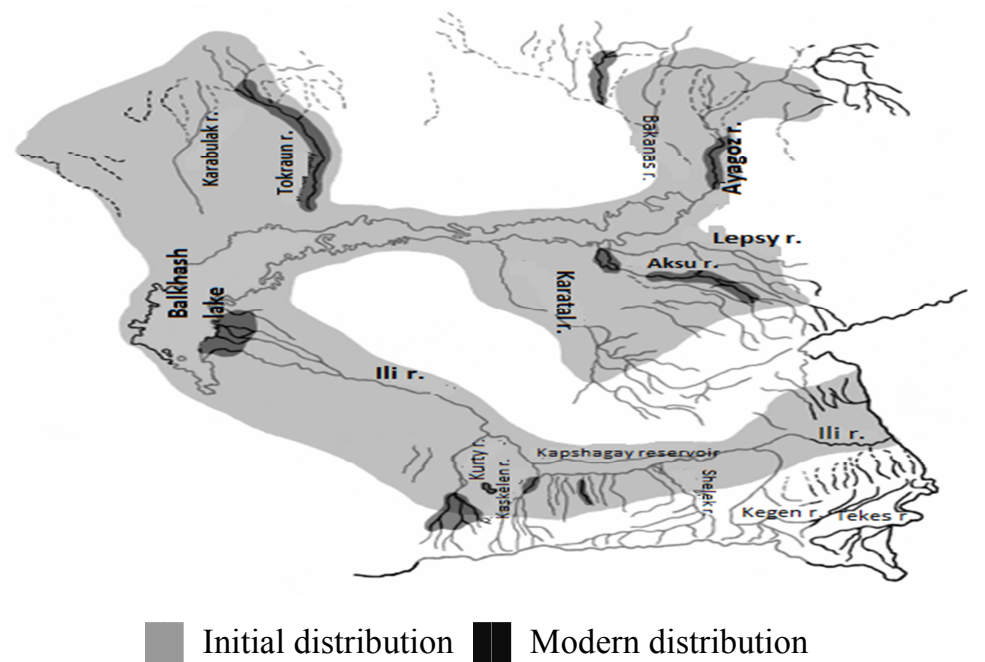

Fig. 4. Area of Balkhash perch in the reservoirs of the Ile-Balkhash basin

The history of developing the abundance of Balkhash perch in the Balkhash basin can be divided into 3 main periods:

1. Natural state.

2. The period of pikeperch acclimatization.

3. The period of extinting number of pikeperch.

Prior to the large-scale acclimatization in the Ile-Balkhash basin, perch was the most abundant species in the lake and tributaries. Its average annual catch in Lake Balkhash in the 1930s reached 4.000 tons.

The main reason for the sharp decline in the number of Balkhash perch in the Ile-Balkhash basin is considered the acclimatization after the reconstruction of ichthyofauna. Perch is called a specific "culprit" of perch elimination, as is the case with Balkhash marinka.

As it was mentioned above, in the eve of the millennium, due to the high market value of perch fillet in European countries, the intensity of its official fishing, as well as poaching, increased, which led to reducing the number of perch in all waters of the Ile-Balkhash basin. Against the background of the suppression of the antagonist, beginning in 2010, Balkhash perch began to appear more and more often in the open areas of Lake Balkhash and the Ile river delta. However, one can hardly expect a significant increase in the number and biomass of perch, because perch, as well as other fish species, is limited to fishing, taking into account the need to maintain the minimum values of their commercial stocks.

Currently, Balkhash perch is represented by isolated populations scattered throughout the basin (Fig. 4). The most numerous perch population is preserved in the lower delta of the Ile river. The current age composition and biological characteristics of delta perch are presented in Table 3.

Table 3

Biological indicators and age composition of Balkhash perch in the delta of the river Ile in 2018

\begin{tabular}{|c|c|c|c|c|c|c|c|}
\hline \multirow{2}{*}{$\begin{array}{c}\text { Age, } \\
\text { years old }\end{array}$} & \multicolumn{2}{|c|}{ Length, cm } & \multicolumn{2}{|c|}{ Mass, $\mathbf{g}$} & \multirow{2}{*}{$\begin{array}{l}\text { Fulton } \\
\text { Fatness }\end{array}$} & \multirow{2}{*}{$\begin{array}{c}\mathrm{N}, \\
\text { individuals }\end{array}$} & \multirow{2}{*}{$\begin{array}{c}\text { Share } \\
\text { of fish in catch, } \%\end{array}$} \\
\hline & $\min -\max$ & average & $\min -\max$ & average & & & \\
\hline 2 & $11-13$ & 12.3 & $29-48$ & 38 & 2.07 & 7 & 15.9 \\
\hline 3 & $14-16$ & 14.6 & $51-85$ & 67 & 2.10 & 15 & 34.1 \\
\hline 4 & $16-18$ & 17.3 & $86-130$ & 105 & 2.03 & 10 & 22.7 \\
\hline 5 & $19-20$ & 19.4 & $124-168$ & 150 & 2.04 & 11 & 25.0 \\
\hline 7 & 25 & 25.0 & 298 & 298 & 1.91 & 1 & 2.3 \\
\hline Total & $11-25$ & 16.3 & $29-298$ & 93 & 2.06 & 44 & 100.0 \\
\hline
\end{tabular}


Analysis of the age composition and size and weight indices indicates a low growth rate of Balkhash perch in delta reservoirs due to high food competition with other predatory fish species. Most likely, the so-called "reed" form of the perch was mainly preserved here.

It is not possible to estimate the current number of perch in Lake Balkhash and river watercourses. First of all, it is not harvested by catching seine nets and gill nets with an allowed mesh spacing of $50 \mathrm{~mm}$ or more, according to the catches of which direct recording of the number of commercial fish species is made. Secondly, the research fishing conducted using small-gear fishing gear (fixed nets with a mesh size of $16 \mathrm{~mm}$ or more) on a standard grid of sampling stations does not provide a complete picture of the distribution and frequency of occurrence of the Balkhash perch in the lake's biotopes, which is more than $600 \mathrm{~km}$ Thirdly, in river beds, the flow velocity in which more than $1 \mathrm{~m} / \mathrm{s}$, the use of any otsetseivayuschimi and oblacheivayuschih fishing gear is very difficult. More favorable conditions for counting the number of Balkhash perch are found in the lake systems of the Ile river delta, where its reserves are estimated at 0.11 million copies.

\section{Measures for the conservation of rare and endangered species}

Of the above rare and endangered fish species of the Ile-Balkhash basin, the most interesting for artificial breeding and replenishment of natural populations are ship, Balkhash marinka and Aral barbel.

The evolutionary development of the endemic ichthyofauna showed that Balkhash perch could cope with the negative impact of biotic and abiotic factors on its population. Upon the occurrence of favorable environmental conditions, the perch managed to recover its number at a certain level in a relatively short period of time. Therefore, at the present stage of development, Balkhash perch from the entire list of protected fish species in the Ile-Balkhash basin is the least worrisome for its fate.

The biotechnology of artificial breeding and cultivation of a thorn in general is already developed and approved at fish factories and farms of Russia and Kazakhstan.

The Balkhash marinka and Aral barbel are of higher fisheries interest as an object of aquaculture and breeding. Due to the heterogeneity of their populations in the remaining habitats during artificial insemination by individual selection of the most early-maturing and well-growing individuals, the breeder can breed a new breed, characterized by earlier puberty and the best growth rate. Marinka and barbel with such qualities can occupy a prominent place in lake fish farming in the arid zone and, possibly, beyond its borders.

Unfortunately, none of the fish-breeding organizations registered in Kazakhstan and 11 hatcheries are not oriented and are not engaged in the reproduction and breeding of rare and endangered fish species. The existing enterprises have not developed technologies for the cultivation of rare species of fish, except thorn.

Thus, to restore the number of Aral barbel and Balkhash marinka, it is necessary to develop the following:

- technology and standards of the formation of the repair brood stock (RBS) of Aral barbel and Balkhash marinka;

- technology and standards for the cultivation of planting material of Aral barbel and Balkhash marinka from the larva stage;

- development of the composition of feed and feeding norms of Aral barbel and Balkhash marinka at various stages of the fish-breeding process;

- search for reservoirs that are promising for stocking with fish stock of Aral barbel and Balkhash marinka.

The program for the restoration and maintenance of the number of rare species should include the following elements:

- assessment of habitat suitability for the protected species;

- development of a protectionist policy towards the protected species;

- develop a policy of suppressing the number of competitors.

Aral ship. As research has shown, ship found favorable conditions in the Ile-Balkhash basin and successfully naturalized, i.e. the environment, in this case, does not limit the existence of a thorn. The limiting factors for increasing the number were:

- mass death of young spike in gillnets;

- small area spawning grounds;

- illegal fishing;

- trophic competition from other benthophages that inhabited Lake Balkhash. 
To restore the number of thorn in the Ile-Balkhash basin, it is necessary to artificially reproduce it, create conditions under which the young will not fall into the nets of fishermen and reduce the number of trophic competitors.

Artificial reproduction. The calculation of the number and biomass of the acclimatizer should be based on the ecological capacity of the ecosystem. In this case, when it comes to rare species, we are dealing with abundance values that fall entirely within the error limits of any calculations. Based on this, we can operate only with absolute values of catches that took place in the historical past.

In the Aral Sea, before the outbreak of the epizootic episode in 1936, spike catches averaged $1.34 \%$ of the total mass of catches. In Lake Balkhash, according to official statistics, the maximum catches did not exceed 30 tons, which is $0.26 \%$ of the mass of fish catches in the lake. To calculate the required stocking volumes, we can proceed from the average spike catches in its natural state, that is, from a population of $1.34 \%$ of the total catches.

Over the past 10 years, catches on Lake Balkhash averaged 10000 tons, so ship catches on average could be 134 tons. The average mass of adult ships (over 9 years old) is $24 \mathrm{~kg}$. Therefore, the estimated number of ship species in the catches would be 5583 . Considering that the standard return from juveniles ( $3 \mathrm{~g})$ is $3 \%$, we obtain the volume of juveniles needed to maintain such catches 186100 ship juveniles.

According to many experts, the return in the amount of $3 \%$ of the released fry is not true, and in fact it is no more than a few tenths of a percent, and never exceeds $1 \%$. With this in mind, the volume of production of young spike should be 558.3 thousand units.

In order to create the Repair brood herd of thorn, it is possible to use individuals of any age captured both in Lake Balkhash and in the Ile river and the Kapshagay reservoir.

A portion of fry for creation of the RBS can be brought from the fish-breeding workshop of the "Aleksinsky Chemical Plant" JSC, where to date the offspring from Aral ship producers, brought in 1996 from the Kapshagai reservoir, have been received.

Work on the creation of the RBS Balkhash spike should be preceded by studying the structure of the spike genome in the Ile-Balkhash basin and developing a genetic passport for each manufacturer.

Work on the creation of the RMS Balkhash spike should be preceded by studying the structure of the thorn genome in the Ile-Balkhash basin and developing a genetic passport for each manufacturer.

To maintain genetic diversity, it is necessary to form RBS of each population with their separate content. At the initial stage, at least it is necessary to keep separately the "Kapshagai" and "Balkhash" ships. In accordance with the existing fish-breeding standards, the total number of RBS in the Balkhash Sturgeon Fish Factory should be 254 individuals. At the same time, it will take 28 years for females to create a RBS consisting entirely of producers of artificial origin, for males - 24 years. In the first years, the catch in natural waters will be 579 units: 450 - females, 129 - males. This number of RBS complies with the recommendations of the Russian SFF who already have experience in creating RBS.

The formation of RBS can be accelerated by catching individuals of any age, including immature ones and introducing them into the reproduction process from the moment they mature in artificial conditions.

Taking into account modern technologies of rearing sturgeon fish species, the hatchery farm can be located on any part of the basin with sufficient fresh water. However, given the plans of the PRC to withdraw water from the Ile, the optimal location of SFF is the estuary of the Karatal.

Changes in fishing mode in Lake Balkhash. The only effective measure to prevent the death of juvenile spines in the meshing fishing gearis to refrain from using gill fixed nets when conducting commercial fishing. However, at Lake Balkhash, such a measure would lead to a noticeable decrease in fish production, since the gill nets are the most massive fishing gear on the pond. A way out of this situation can only be the allocation of "zones of rest", in which fishing with the help of meshing fishing gear will be prohibited and fishing only with seines or other drainage fishing gear is allowed. As such rest zones, all deep-water areas on Lake Balkhash can be offered. In these zones, fishing with gillnets should be prohibited all year round. All thorn fish caught by filtering-type fishing gearshould be released in live form with the registration of all such cases in the trade log.

In addition, it is necessary to create favorable conditions for feeding thorn in the reservoir by reducing the pressure of trophic competition. The main trophic competitors of thorn in Balkhash are carp, bream and pikeperch. At present, the number of carp and pikeperch is low due to the intensive 
development of their stocks by fisheries, while the stocks of bream are underutilized. To reduce the competition of bream and thorn, it is necessary to take measures to reduce the number of bream.

Alternative ways to save. Given the high risk of the existence of a natural population in Lake Balkhash, measures must be taken to reduce the risk of extinction of this species in its natural habitat. Such measures are the development of commercial cultivation and the reacclimatization of thorn.

Thus, to increase and maintain the number of thorns in Lake Balkhash, the following measures must be taken:

- artificial reproduction of thorn based on the newly created Balkhash SFF;

- isolation of "rest zones" with the prohibition of the use of fishing gear in these zones;

- reducing the number of trophic competitors thorn. First of all bream;

- creating artificial thorn populations with the production of marketable products Settlement of ship, in order to reduce the risk of extinction of the species and, first of all, the reacclimatization of the thorn in the Aral Sea.

Aral barbel. To restore and preserve the number of Aral barbel in the Ile-Balkhash basin, it is necessary to artificially reproduce it with the release of young fish into natural reservoirs and the creation of an artificial population.

The number of spawning herds of barbel in the lower reaches of the river Ile was 3 thousand individuals. Given that the majority of producers spawn in a year, and part (about 1/3) 1 time in three years, we can estimate the total number of the mature part of the population of 7 thousand individuals. In order to ensure annual replenishment in such a volume, with a $2 \%$ return, it is necessary to produce annually in the lake Balkhash and the delta of the river Ile 350 thousand 1.5-gram young Aral barbel.

The formation of RBS should be carried out as well as by the example with the Aral thorn in two ways:

1. Growing producers to sexual maturity in artificial conditions "from the egg".

2. The domestication of mature individuals caught in natural reservoirs.

For the formation of broodstock, there will not be enough producers caught in the Ile-Balkhash basin. To speed up the formation, it is necessary to deliver the young from the Syr Darya river basin, caught in rice checks.

Balkhash marinka. The experience gained allows us to partially develop the alleged fish-technical standards for the artificial reproduction of the Balkhash marinka (Table 4).

Table 4

Estimated fish farming and technical standards for cultivating Balkhash marinka juveniles

\begin{tabular}{|c|c|}
\hline Readings & Standards \\
\hline \multicolumn{2}{|c|}{ Aging producers, collecting and incubation of eggs } \\
\hline Average piece female weight, $\mathrm{kg}$ & 0.4 \\
\hline Average piece male weight, $\mathrm{kg}$ & 0.3 \\
\hline Ratio of producers (female/male) & $1: 3$ \\
\hline Waste of producers in transportation, $\%$ & 3 \\
\hline Waste of producers in ageing, $\%$ & 20 \\
\hline Maturation of producers after injection, $\%$ & 85 \\
\hline Number of females with good quality eggs after maturation, $\%$ & 85 \\
\hline Fertilization of eggs, $\%$ & 85 \\
\hline \multicolumn{2}{|c|}{ Aging and Rearing of larvae } \\
\hline Hatching larvae from eggs laid for incubation, $\%$ & 70 \\
\hline Hatching larvae from cages, $\%$ & 90 \\
\hline \multicolumn{2}{|c|}{ Growing fry } \\
\hline Average piece fry mass, $g$ & 1.5 \\
\hline Terms of broodstock raising, night & $25-30$ \\
\hline
\end{tabular}

The following data can be used to calculate the required amount of under-grown young marinka for releasing it into natural water bodies (Lake Balkhash, the Ile, the Karatal, the Lepsy). In 1968 the total catch in Lake Balkhash was 14.540 tons, of which 170 tons came to Balkhash marinka (1.2\%). It should be noted that this was the last year when the catch reached 100 tons. By that time, the main share in catches came to carp (over 70\%), bream (over 1.000 tons) and pike perch (over 2.000 tons) [11]. 
With average weighed portion of $550 \mathrm{~g}$, the number of matured marinka species made 309000 . To ensure the annual replenishment of commercial stocks of such volume, with $2 \%$ of return, it is necessary to release 15.5 million species of Balkhash marinka in Lake Balkhash and the tributaries annually.

\section{Recommendations}

To implement the measures developed above, it is proposed to create the Balkhash Selection and Genetic Center with three sites: for sturgeon, Aral barbel, marinka.

The scheme of the biotechnological process for all species is the same (Fig. 5); it implies formation in the Center repair brood stocks (RBS) in a mixed way due to catching of producers in their natural habitat and cultivation "ab larva".

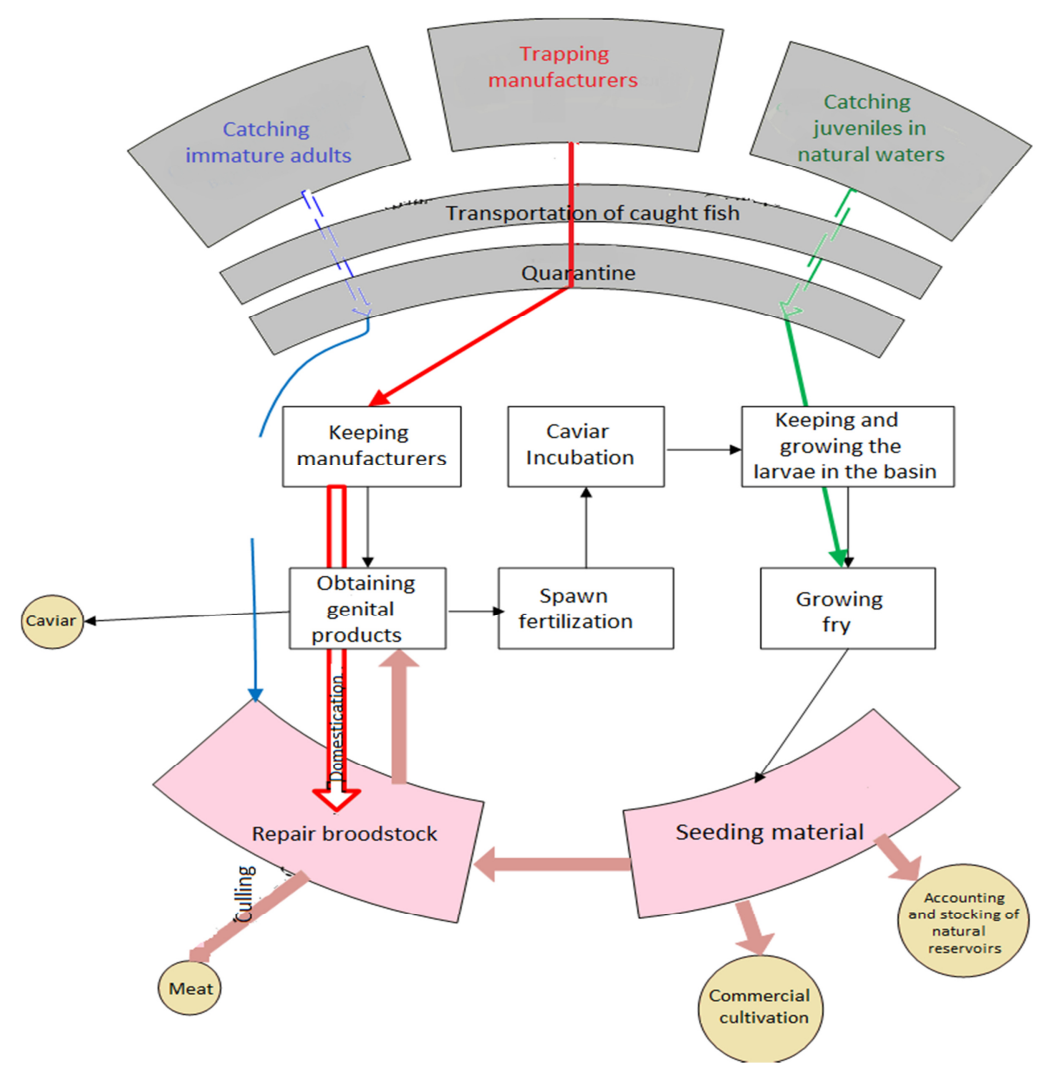

Fig. 5. Diagram of biotechnological process of Balkhash Selection and Genetic Center

In order to form the structure of RBS, which is able to preserve the genetic diversity of protected species, activities on creating RBS must be preceded by the research of the natural genetic structure of these species.

In terms of the practical prerequisite for Aral barbel, it will be necessary to create three groups in RBS structure:

1. Nizhneiley - for species caught in the lower side of the Kapshagai dam.

2. Verkhneiley - for species caught in the upper race of the Kapshagay dam.

3. Russian - for descendants of Aral barbel caught in the Kapshagai reservoir in the 1990s, of which the RMS of Aral barbel was formed in the Russian hatcheries.

Two groups were planned to be created for Aral barbel:

1. Balkhash group - for species caught in the Ile-Balkhash basin.

2. Syr Darya group - for species caught in the Syr Darya.

For Balkhash marinka it is possible to form several groups in the places of their capture:

1. Tokyraun group.

2. Karatal group.

3. The Aksu. 


\section{Lepsinsky group.}

5. Ayagoz group.

The number of such groups may fluctuate depending on the conditions of natural populations and technical capabilities of the Selection and Genetic Center.

\section{Conclusions}

1. Currently taken conservation measures are ineffective and do not ensure the sustainable existence of natural populations.

2. To restore and maintain the abundance of Aral barbel in the Ile-Balkhash basin, special measures are needed - artificial reproduction, changes in the Fishery Rules and organization of commodity cultivation.

3. For artificial cultivation it is necessary to create a Balkhash breeding and genetic center with three sites: for sturgeon, Aral barbel, and marinka. Each site requires the formation of RBS.

4. The power of the sturgeon site is 558.300 ship juveniles weighing $3 \mathrm{~g}$ for annual release into Lake Balkhash.

5. To prevent the death of ship juveniles in fishing gear it is necessary to create zones of rest in the deepest parts in the east of Lake Balkhash.

6. The power of Aral barbel site is 350.000 species with mass 1.5-gram for annual release into Lake Balkhash.

7. The power of marinka site is 15.5 million species with mass $1.5 \mathrm{~g}$ for annual release into Lake Balkash and the Ile, Karatal, Lepsy rivers.

8. In order to preserve the natural populations of Balkhash marinka and Balkhash perch it is necessary to create a network of protected natural ichthyological zones in the sectors of the Ile-Balkhash basin where pike perch wouldn't penetrate. One of such sites is the Tokyraun river.

\section{REFERENCES}

1. Convention on Biological Diversity. Rio de Janeiro, 1992. Available at: cbd.int $>$ doc/legal/cbd-en.pdf (accessed: 15.05.19)

2. Maksakovskij V. Geograficheskaya kartina mira: posobie dlya vuzov [Geographical picture of the world: teaching guide for universities]. Moscow, Drofa Publ., 2008. B. I: Obshchaya harakteristika mira. Global'nye problemy chelovechestva. P. 495.

3. Isbekov Қ. В., Olpejisov Sh. Ә. Rybnoe hozyajstvo Kazahstana: Sovremennoe sostoyanie i perspektivy razvitiya [Fisheries of Kazakhstan: Current state and future development]. Balyқ sharuashylyķtarynył basymdyқ̧tary men daтu bolashazy: halyқ̧aralyқ zylymi-tzzhirbielik konferenciya materialdary. Almaty, 2014. Pp. 5-7.

4. Kompleksnaya ocenka ekologo-epidemiologicheskogo sostoyaniya bioresursov osnovnyh rybohozyajstvennyh vodoemov Kazahstana dlya formirovaniya gosudarstvennogo kadastra. Razdel: Kapshagajskoe vodohranilishche i reka Ili: otchet o NIR (zaklyuchitel'nyj). [Comprehensive assessment of ecological and epidemiological state of biological resources of major fishery reservoirs of Kazakhstan for creating the state cadastre. Section: the Kapshagai Reservoir and the Ili River: research report (final)] Almaty, KazNIIRH, 2011. P. 105.

5. Pravdin I. F. Rukovodstvo po izucheniyu ryb [Instructions on studying fish]. Moscow, Pishchevaya promyshlennost' Publ., 1966. 376 p.

6. Kushnarenko A. I., Lugarev E. S. Ocenka chislennosti ryb po ulovam passivnymi orudiyami [Estimation of fish abundance by catching fish with passive fishing gears]. Voprosy ikhtiologii, 1983, vol. 23, iss. 6, pp. 921-926.

7. Isbekov K. B., Timirhanov S. R. Redkie ryby ozera Balhash [Rare fish species of Lake Balkhash]. Almaty, 2009. Pp. 8-14.

8. Isbekov K. B. Vozdejstvie ekologicheskih faktorov na sostoyanie redkih i ischezayushchih vidov ryb ozera Balkash i perspektivy ih sohraneniya. Avtoreferat dis. ... kand. biol. nauk [Impact of environmental factors on rare and endangered fish species of Lake Balkash and chances for their preservation. Diss.Abstr. ... Cand. Biol. Sci.]. Almaty, 2010. P. 9.

9. Temirhanov S. R. Oroshenie kak faktor sohraneniya aborigennoj ihtiofauny Balhash-Alakol'skogo bassejna [Irrigation as a factor in conservation of native ichthyofauna of the Balkhash-Alakol basin]. Pervyj kongress ihtiologov Rossii: tezisy dokladov. Astrahan', Moscow, 1997. Pp. 103-110.

10. Mamilov N. Sh., Balabieva G. K., Mitrofanov I. V. Problemy sohraneniya aborigennoj ihtiofauny IliBalhashskogo bassejna [Problems of conservation of native ichthyofauna of the Ili-Balkhash basin]. Vestnik Kazahskogo nacional'nogo universiteta im. al'-Farabi. Seriya ekologicheskaya, 2012, no. 1, pp. 37-42.

11. Baimbetov A. A., Mitrofanov V. P., Timirhanov S. R. Marinka balhashskaya [Balkhash marinka]. Ryby Kazahstana: v 5 t. Alma-Ata, Nauka Publ., 1988. Vol. 3. Pp. 57-83. 


\title{
INFORMATION ABOUT THE AUTHORS
}

Isbekov Kuanysh Baibolatovich - Republic of Kazakhstan, 050016, Almaty; Fisheries Research and Production Center, LLP; Candidate of Biology; General Director; isbekov@mail.ru.

Assylbekova Saule Zhangirovna - Republic of Kazakhstan, 050016, Almaty; Fisheries Research and Production Center, LLP; Doctor of Biology; Deputy General Director; assylbekova@mail.ru.

Zharkenov Damir Kayirkeldyevich - Republic of Kazakhstan, 050016, Almaty; Fisheries Research and Production Center, LLP; Candidate of Biology; Chief Academic Secretary; zharkenov80@mail.ru.

Tsoi Vyacheslav Nikolaevich - Republic of Kazakhstan, 050016, Almaty; Fisheries Research and Production Center, LLP; Branch Director; tsoy-balkhash@mail.ru.

Zhaparova Maral Aydynkyzy - Republic of Kazakhstan, 050010, Almaty; Kazakh National Agrarian University; Master's Course Student; m.zhaparova00@mail.ru.

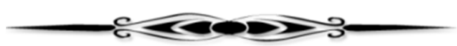

\section{СОВРЕМЕННОЕ СОСТОЯНИЕ И ПЕРСПЕКТИВЫ \\ ИСКУССТВЕННОГО РАЗВЕДЕНИЯ РЕДКИХ, ИСЧЕЗАЮЩИХ \\ ВИДОВ РЫБ ДЛЯ СОХРАНЕНИЯ БИОРАЗНООБРАЗИЯ И ВОССТАНОВЛЕНИЯ ЧИСЛЕННОСТИ В ЕСТЕСТВЕННЫХ ВОДОЕМАХ ИЛЕ-БАЛКАШСКОГО БАССЕЙНА}

\author{
К. Б. Исбеков ${ }^{1}$, С. Ж. Асылбекова ${ }^{1}$, Д. К. Жаркенов ${ }^{1}$, В. Н. Цой ${ }^{1}$ М. А. Жапарова ${ }^{2}$ \\ ${ }^{1}$ ТОО «Научно-производственный иентр рыбного хозяйства», \\ Республика Казахстан, Алматы \\ ${ }^{2}$ Казахский национальный аграрный университет, \\ Республика Казахстан, Алмать
} кашского бассейна, пострадавшей в результате проведения широкомасштабных акклиматизационных работ. Четыре вида из состава ихтиофауны бассейна занесены в Красную Книгу Казахстана: шип (Acipenser nudiventris Lovetsky, 1828), усач аральский (Barbus brachycephalus brachycephalus Kessler, 1872), маринка балхашская (Schizothorax argentatus argentatus Kessler, 1874), окунь балхашский (Perca schrenkii Kessler, 1874). Ввиду малоэффективности рыбоохранных мероприятий, в числе которых введение запрета на вылов этих рыб, которые не встречаются нигде, кроме Иле-Балкашского бассейна, необходимы искусственное воспроизводство, изменения в Правилах рыболовства и организация товарного выращивания. В основе работы - материалы исследований 2001-2018 гг., проведенных в акватории оз. Балкаш, дельте и нижнем течении р. Иле, р. Токраун. Охарактеризовано состояние популяций шипа (Acipenser nudiventris Lovetsky, 1828), усача аральского (Barbus brachycephalus brachycephalus Kessler, 1872), маринки балхашской (Schizothorax argentatus argentatus Kessler, 1874), окуня балхашского (Perca schrenkii Kessler, 1874). Установлены основные причины, препятствующие поддержанию высокой численности исчезающих видов: малая площадь естественных нерестилищ, гибель молоди в объячеивающих орудиях лова, большой объем нелегального промысла (шип); ухудшение условий естественного воспроизводства, браконьерство, массовая гибель молоди в ирригационной системе (усач аральский); тотальная элиминация и пищевая конкуренция с судаком (маринка балхашская, балхашский окунь). Рассмотрены перспективы сохранения редких и исчезающих видов рыб, предложены рекомендации по разведению и пополнению популяций видов, занесенных в Красную Книгу, в частности, мероприятия по искусственному воспроизводству и предотвращению гибели молоди, созданию благоприятных условий для нагула и снижению пресса трофической конкуренции. Без принятия адекватных мер по снижению антропогенного воздействия на природные ресурсы, в том числе на ихтиофауну, численность основных промысловых видов рыб сократится, исчезнут редкие виды рыб. 
Ключевые слова: Красная Книга, миграция, усач аральский, окунь балхашский, шип, маринка балхашская, бассейн.

Для цитирования: Исбеков К. Б., Асылбекова С. Ж., Жаркенов Д. К., Цой В. Н., Жапарова М. А. Современное состояние и перспективы искусственного разведения редких, исчезающих видов рыб для сохранения биоразнообразия и восстановления численности в естественных водоемах Иле-Балкашского бассейна // Вестник Астраханского государственного технического университета. Серия: Рыбное хозяйство. 2019. № 3. С. 17-30. DOI: 10.24143/2073-5529-2019-3-17-30.

\section{СПИСОК ЛИТЕРАТУРЫ}

1. Convention on Biological Diversity. Rio de Janeiro, 1992. URL: cbd.int>doc/legal/cbd-en.pdf (дата обращения: 15.05.19).

2. Максаковский В. Географическая картина мира: пособие для вузов. М.: Дрофа, 2008. Кн. I: Общая характеристика мира. Глобальные проблемы человечества. С. 495.

3. Исбеков Қ. Б., Әлпейісов Ш. Ә. Рыбное хозяйство Казахстана: современное состояние и перспективы развития // Балық шаруашылықтарының басымдықтары мен даму болашағы: халықаралық ғылымитәжірбиелік конференция материалдары. Алматы, 2014. С. 5-7.

4. Комплексная оценка эколого-эпидемиологического состояния биоресурсов основных рыбохозяйственных водоемов Казахстана для формирования государственного кадастра. Раздел: Капшагайское водохранилище и река Или: отчет о НИР (заключительный). Алматы: КазНИИРХ, 2011. С. 105.

5. Правдин И. Ф. Руководство по изучению рыб. М.: Пищ. пром-сть, 1966. 376 с.

6. Кушнаренко А. И., Лугарев Е. С. Оценка численности рыб по уловам пассивными орудиями // Вопросы ихтиологии. 1983. Т. 23. Вып. 6. С. 921-926.

7. Исбеков К. Б., Тимирханов С. Р. Редкие рыбы озера Балхаш. Алматы, 2009. С. 8-14.

8. Исбеков К. Б. Воздействие экологических факторов на состояние редких и исчезающих видов рыб озера Балкаш и перспективы их сохранения: автореф. дис. ... канд. биол. наук. Алматы, 2010. С. 9.

9. Темирханов С. Р. Орошение как фактор сохранения аборигенной ихтиофауны Балхаш-Алакольского бассейна // Первый конгресс ихтиологов России: тез. докл. Астрахань; М., 1997. С. 103-110.

10. Мамилов Н. Ш., Балабиева Г. К., Митрофанов И. В. Проблемы сохранения аборигенной ихтиофауны Или-Балхашского бассейна // Вестн. Казах. нац. ун-та им. аль-Фараби. Сер. экологическая. 2012. № 1. C. $37-42$.

11. Баимбетов А. А., Митрофанов В. П., Тимирханов С. Р. Маринка балхашская // Рыбы Казахстана: в 5 т. Алма-Ата: Наука, 1988. Т. 3. С. 57-83.

Статья поступила в редакцию 04.06.2019

\section{ИНФОРМАЦИЯ ОБ АВТОРАХ}

Исбеков Куаныш Байболатович - Республика Казахстан, 050016, Алматы; ТОО «Научно-производственный центр рыбного хозяйства»; канд. биол. наук; генеральный директор; isbekov@mail.ru.

Асылбекова Сауле Жангировна - Республика Казахстан, 050016, Алматы; ТОО «Научно-производственный центр рыбного хозяйства»; д-р биол. наук; зам. генерального директора; assylbekova@mail.ru.

Жаркенов Дамир Кайыркельдыевич - Республика Казахстан, 050016, Алматы; ТОО «Научно-производственный центр рыбного хозяйства»; канд. биол. наук; главный ученый секретарь; zharkenov80@mail.ru.

Цой Вячеслав Николаевич - Республика Казахстан, 050016, Алматы; ТОО «Научно-производственный центр рыбного хозяйства»; директор Балхашского филиала; tsoy-balkhash@mail.ru.

Жапарова Марал Айдынкызы - Республика Казахстан, 050010, Алматы; HАО «Казахский Национальный аграрный университет»; магистр с.-х. наук; m.zhaparova00@mail.ru. 